\title{
Accounting for business combinations and takeover premiums: pre- and post- IFRS
}

\author{
By \\ Martin Bugeja* \\ Martin.Bugeja@uts.edu.au \\ University of Technology, Sydney \\ PO Box 123, Broadway NSW 2007, Australia \\ Anna Loyeung \\ Anna.Loyeung@uts.edu.au \\ University of Technology, Sydney \\ PO Box 123, Broadway NSW 2007, Australia
}

\begin{abstract}
The adoption of International Financial Reporting Standards (IFRS) in Australia in 2005 resulted in goodwill accounting shifting from systematic annual amortisation to impairment testing. We examine whether IFRS adoption changed the association between takeover premiums and the difference between a target firm's pre-acquisition market and book values (pre- acquisition step-up). Our results show a negative association between takeover premiums and the pre-acquisition step-up of the target firm. This association reduces however, after Australia adopted IFRS and no longer required goodwill amortisation. Consistent with the incentives arising from contracts written around accounting numbers, our results are strongest for bidding firms which compensate their CEO using an accounting-based bonus plan. These results are robust to a battery of sensitivity tests.
\end{abstract}

1.

\footnotetext{
* Corresponding author: Martin Bugeja, Accounting Discipline Group, The University of Technology Sydney, 2007, New South Wales, Australia. Telephone + 6129514 3743, fax + 61295143669.

E-mail address: martin.bugeja@uts.edu.au.

Acknowledgments: This paper has benefited from comments received from Lucy Chen, Robert Czernkowski, Peter Easton, Zoltan Matolcsy, Peter Wells, Anne Wyatt, and participants at the 2012 American Accounting Association International Accounting Section Mid-Year Conference, the 2012 British Accounting and Finance Association Annual Conference and the 2012 European Accounting Association Annual Congress.
} 


\section{Introduction}

The method of accounting for a business combination has long been controversial. A significant issue in this debate is how to account for the difference between the acquisition price and the book value of the target firm's net assets at the acquisition date (i.e., step-up). ${ }^{1}$ Interestingly, this debate exists even though the accounting method for the step-up has no cash flow consequences. As such, the reason for contention over the appropriate accounting method typically focuses on how the method of accounting leads to lower post- acquisition earnings if all or part of the step-up is subject to systematic amortisation or depreciation charges (Gagnon, 1967; Copeland and Wodjak, 1969 and Aboody et al., 2000).

We contribute to this debate by investigating the association between takeover premiums and the target firm step-up and whether any association is influenced by the financial reporting environment and CEO compensation incentives. Specifically, we investigate: i) the association between the target firm pre-acquisition step-up and premiums; ii) whether this association changed when Australia adopted International Financial Reporting Standards (IFRS) and iii) whether any association between premiums and the target firm pre-acquisition step-up is driven by incentives arising from accounting-based compensations plans offered to the bidding firm CEO.

Due to the mechanical relationship between premiums and the step-up we cannot directly test for an association but instead rely on a proxy measure. This measure is calculated as the target firm market capitalisation two months prior to the takeover announcement minus the book value of target firm equity at the end of the prior financial year. We refer to this measure as the

\footnotetext{
${ }^{1}$ To highlight the divergence in opinion over the method of accounting for the step-up, the last 15 years has seen the International Accounting Standards Board (IASB) and U.S. Financial Accounting Standards Board (FASB) move from goodwill amortisation to goodwill impairment; the FASB prohibit the pooling method of accounting and the U.K. Accounting Standards Board disallowing the direct write-off of goodwill against reserves.
} 
pre-acquisition step-up. As this measure is unaffected by the offer price it avoids a mechanical relationship.

The motivations for this study are twofold. Firstly, prior studies examine many factors as explaining premiums. These factors include: payment method (Huang and Walkling, 1987; Draper and Paudyal, 1999; Da Silva Rosa et al., 2000), takeover competition and hostility (Bates and Lemmon, 2003; Chapple et al., 2007), target firm ownership structure (Stulz, 1988), and target firm leverage and free cash flow (Jensen., 1986; Israel, 1991). However, minimal attention has been given to whether takeover premiums are associated with the method used to account for a business combination.

Building on earlier U.S. research (Aboody et al., 2000 and Ayers et al., 2002), we contend that if accounting standards require goodwill amortisation (i.e., pre-IFRS) bidding firms minimise the premium offered to target firms with a higher pre-acquisition step-up. This contention is based on managers' incentives to maximise reported income. In contrast, we expect that this association is reduced when accounting standards are revised to remove systematic goodwill amortisation (i.e., post-IFRS). To support our argument that the association between premiums and the target firm pre-acquisition step-up is driven by incentives to maximise reported earnings, we expect that our predictions hold only for bidding firms which remunerate CEOs using accounting-based bonus plans.

Secondly, numerous studies have examined the impact of IFRS adoption on users of financial information with many studies reporting benefits following adoption (e.g., Barth et al., 2008, Chalmers et al., 2011a, Chalmers et al., 2012, Cotter et al., 2012; Brochet et al., 2013). ${ }^{2}$ Our study extends this body of work by examining if IFRS adoption impacted firms' economic decision making and highlights possible negative consequences of IFRS adoption.

\footnotetext{
${ }^{2}$ In contrast, to these results Lai et al. (2013b) document a reduction in accrual reliability after IFRS adoption.
} 
We test our contentions using a sample of Australian takeovers before and after IFRS adoption. We find a negative association between takeover premiums and the target firm pre-acquisition step-up with this association reducing after Australia's adopted IFRS. Further analysis indicates that these findings occur only where the bidding firm remunerates the CEO using an accounting-based bonus plan. Our results are robust to a battery of sensitivity tests.

This study makes a number of contributions. Firstly, we extend prior research by examining the contractual incentives (Clinch, 1995) which influence the association between takeover premiums and goodwill accounting methods (Robinson and Shane, 1990; Choi and Lee, 1991; Ayers et al., 2002; James et al., 2008). This study also adds to literature examining the impact of Australia's adoption of IFRS, and more specifically, the move from goodwill amortisation to goodwill impairment (Chalmers et al., 2011b). Our results suggest that the move to goodwill impairment led to bidding firms paying a higher premium for target firms with a higher preacquisition step-up resulting in a greater potential wealth transfer from bidding to target firm shareholders.

We also add to prior literature studying the effect of management compensation plans on accounting choice (Fields et al. 2001 and Armstrong et al. 2010). Our evidence is consistent with CEOs responding to the incentives provided from their compensation structure to take advantage of a change in accounting practices to maximise potential personal gains (e.g., Beneish 1999; Bebchuk and Fried, 2005).

The remainder of this study is organised as follows. Section 2 describes the accounting rules which apply to the step-up. Prior research and hypotheses are discussed in section 3 , whilst section 4 presents the research design. Section 5 describes the sample selection and presents descriptive statistics. Results are provided in section 6 and section 7 concludes the study.

\section{Accounting for the step-up in target firm net assets}


AASB 1013, introduced in 1988, was the first mandatory Australian accounting standard applying to the recognition and measurement of the step-up. The standard required the step-up to be first recognised by adjusting target firm's recorded net assets and all identifiable intangible assets to their fair value. Any remaining difference is then recorded as goodwill and amortised over a maximum life of 20 years. ${ }^{3}$ Although, this accounting method has no cash flow effects, it has the effect of reducing post- acquisition. After the adoption of IFRS in 2005 AASB 136 Impairment of Assets required that goodwill was no longer amortised but subject to annual impairment testing. ${ }^{4}$

In contrast to Australia, preceding the issue of SFAS 141 Business Combinations in 2001, acquiring firms in the U.S. could avoid recording the step-up and the higher subsequent depreciation and amortisation charges by structuring an acquisition to qualify for the use of pooling accounting (Accounting Principles Board Opinion No.16, Business Combinations). From 2001, SFAS 142 Goodwill and Other Intangible Assets, mandated the use of the purchase method and removed the requirement for goodwill amortisation.

\section{Prior research and hypotheses development}

Early Australian studies document, that, many firms prefer to avoid goodwill amortisation. For example, Gibson and Francis (1975) and Anderson and Zimmer (1992) show that prior to AASB 1013, the most common methods of accounting for goodwill avoided systematic goodwill amortisation. Furthermore, after the introduction of AASB 1013 firms continued to oppose goodwill amortisation with some firms claiming that the necessity to amortise goodwill meant they were at a competitive disadvantage in the international acquisition arena (Porter, 1994; Miller, 1995).

\footnotetext{
${ }^{3}$ Unlike the U.S., Australian accounting standards did not allow the use of the pooling method of accounting for a business combination.

${ }^{4}$ The adoption of IFRS resulted in other changes to Australian accounting principles. The impact of these other changes is considered in more detail in section 6.3.
} 
Given the lack of a cash flow effect, the motivation of managers to avoid goodwill amortisation is generally explained by incentives associated with reporting higher profit. For example, prior U.S. studies conclude that firms structured acquisitions to qualify for the pooling method of accounting in order to report increased profit (Gagnon, 1967; Copeland and Wodjak, 1969). In addition, Aboody et al. (2000) and Ayers et al. (2002), show that the use of the pooling method is more likely for target firms which have a greater step-up. ${ }^{5}$ They argue that firms prefer to account for these acquisitions using pooling because the higher step-up would otherwise result in material levels of income reducing depreciation and amortisation charges if accounted for using the purchase method.

The impact of incentives arising from management compensation plans on accounting choice has been widely studied in prior research (Fields et al., 2001). In the context of accounting for business combinations, Gore et al. (2000) show that manager's preference for the capitalisation and amortisation of goodwill in the U.K. is lower when managers are compensated using bonus schemes based on rolling GAAP. Aboody et al. (2000) examine the choice between the pooling and purchase method in the U.S. and document that the use of the pooling method increases significantly for target firms with a greater step-up when the CEO of the acquirer is paid a bonus based on accounting earnings.

More recently, Shalev et al. (2013) find that following the removal of goodwill amortisation managers compensated using accounting-based bonus plans allocated a greater percentage of the acquisition price to goodwill. Consistent with this result, Ramanna (2008) finds that firms which lobbied on the exposure draft preceding SFAS 142 removing goodwill amortisation paid significantly higher bonuses to their CEOs. Other studies have documented that firms are less likely to record a goodwill impairment charge when they have an accounting-based bonus plan

\footnotetext{
${ }^{5}$ Consistent with this study, to avoid a mechanical relationship Ayers et al. (2002) use a measure of the target firm's pre-acquisition step-up as a proxy for the actual step-up in an acquisition.
} 
in place (Beatty and Weber, 2006) and the recognition of a goodwill impairment charge results in lower CEO compensation (Darrough et al. 2014).

Since the step-up is calculated as the difference between the acquisition price and the book value of the target firm's net identifiable assets, higher takeover premiums by definition result in a higher step-up. Given managers' preference for maximising reported income, the method of accounting for the step-up is therefore, likely to influence the size of the premium offered. That is, when the step-up, or a greater proportion of the step-up needs to be expensed bidding firm managers are expected to be more reluctant to increase the size of the step-up by offering higher premiums.

This association between takeover premiums and the method of accounting for goodwill has been examined in a number of prior studies. Choi and Lee (1991) compare premiums in the U.K. with those in the U.S. and report significantly higher premiums in the U.K. This result is explained by the ability of U.K. acquirers (during the period of that study) to write-off goodwill immediately against reserves rather than amortise the amount to income. Findings from the U.S. (Robinson and Shane, 1990 and Ayers et al., 2002) also indicate that bidding firms which do not need to amortise goodwill (i.e., when using the pooling method) pay an additional premium relative to acquisitions which are required to amortise goodwill. ${ }^{6}$ Other studies also indicate that acquirers are willing to pay an additional premium in acquisitions in which goodwill can be claimed as a tax deduction (Lee and Choi, 1992; Ayers et al., 2000).

Building on these prior findings we predict that there is an association between the method of accounting for the step-up and takeover premiums in Australia. Prior to 2005, Australian firms amortised that part of the step-up recorded as goodwill. As the size of the premium mechanically increases the step-up a higher premium is likely to result in greater future

\footnotetext{
${ }^{6}$ In contrast, Nathan (1988) finds a negative association between premiums and the target firm pre-acquisition step-up.
} 
amortisation charges. Assuming bidding firm managers are concerned with the impact of amortisation on post- acquisition profit they have an incentive to constrain the size of the premium. Furthermore, this issue is exacerbated in takeovers where the difference between a target firm's pre-acquisition market and book values (i.e., pre-acquisition step-up) is large as bidding firm managers already confront a large write-up in target firm assets. U.S. research (Aboody et al., 2000 and Ayers et al., 2002) for instance, documents that it is these target firms (i.e., those with a large pre-acquisition step-up) which were more likely to be acquired using a pooling transaction. As Australian bidders were not allowed the option of using pooling accounting for such target firms, we expect that they instead respond by minimising any further increase in the step-up by lowering takeover premiums. This leads to our first hypothesis:

$H_{1}$ : Prior to the adoption of IFRS, there is a negative association between takeover premiums and the target firm pre-acquisition step-up.

Prior Australian evidence is however, inconsistent with this hypothesis. James et al. (2008) analyse the association between takeover premiums and the target firm pre-acquisition step-up before and after the introduction of AASB 1013. They find a negative association between the target firm pre-acquisition step-up and premiums with this negative association weakening after AASB 1013's introduction.. A possible explanation for these inconsistent findings is that the pre- AASB 1013 firms in James et al. (2008) used a multitude of different accounting methods, which reduces the ability of their analysis to assess the impact of the introduction of the accounting regulation.

Although non-Australian studies present results consistent with $H_{l}$ they are subject to a number of weaknesses. First, as noted by Clinch (1995), they do not test if the association between the method of accounting and takeover premiums is driven by contracts written around accounting numbers such as management compensation plans. This study addresses this weakness. Second, the U.S. findings are subject to alternative explanations. For instance, the higher 
premium in pooling acquisitions is possibly explained by the superior bargaining position of the target in these transactions because, as described by Nathan (1988), the criteria to qualify for pooling under APB 16 required the support of the target firm. In addition, it is possible that firms' which are accounted for using the pooling and purchase method differ across multiple dimensions and it is these dissimilarities which lead to differing premiums rather than the difference in accounting methods (Clinch 1995). This endogeneity concern has been acknowledged in prior U.S. research (Robinson and Shane, 1990 and Ayers et al. 2002). As Australia has never allowed a choice between the purchase and pooling method, this study is not subject to such endogeneity concerns. Additionally, by limiting our study to one country we avoid problems arising from comparing takeover premiums across countries with different institutional environments (e.g., Choi and Lee 1991).

After the adoption of IFRS, Australian firms no longer amortise goodwill. In consequence, we expect bidding firm managers were less concerned with adding to the size of a target firm's pre-acquisition step-up through the payment of a higher premium as the portion of the actual step-up recorded as goodwill would no longer reduce post- acquisition profit. As such, we predict that post- IFRS, the negative association between the target firm pre-acquisition stepup and the takeover premiums lessens. ${ }^{7}$ This expectation is formally stated as:

$\mathrm{H}_{2}$ : After the adoption of IFRS, the negative association between takeover premiums and the target firm pre-acquisition step-up reduces.

Our two hypotheses assume managers' have a preference for choosing accounting methods to maximise reported profit. A contractual incentive to maximise reported profit arises from the use of management compensation plans and earlier studies indicate that managers often make

\footnotetext{
${ }^{7}$ It is acknowledged that after Australia's adoption of IFRS, it is possible that post- acquisition profit may be reduced due to goodwill impairment. A goodwill impairment charge differs to goodwill amortisation however, as it is not a certain systematic annual charge to profit and managers have arguably more discretion as to when the charge is recorded. Furthermore, at the time of announcing a takeover, bidding firm management is unlikely to contemplate the need to impair goodwill particularly if they are 'infected' with hubris (Roll 1986).
} 
accounting choices to maximise possible bonuses (Fields et al., 2001). In relation to the accounting for acquisitions, prior research shows that the preference for adopting accounting methods which avoid a reduction in post-acquisition earnings are greater for firms which use management compensation contracts linked to accounting numbers (Aboody et al., 2000 and Gore et al., 2000).

Before IFRS adoption the income decreasing effect of goodwill amortisation has a direct personal financial consequence to Australian CEOs with an accounting based performance plan in place. These CEOs also received the most financial benefit from the change in accounting method from goodwill amortisation to impairment testing. In contrast, for CEOs without an accounting-based bonus plan in place the method of accounting for goodwill has no direct financial consequences. As a result, $H_{3}$ predicts that the negative association between takeover premiums and the target firm pre-acquisition step-up pre- IFRS $\left(H_{1}\right)$ and the reduction of this association after Australia's adoption of IFRS $\left(\mathrm{H}_{2}\right)$ exists only for bidding firms with a CEO who is compensated using an accounting-based bonus plan.

$H_{3}$ : The negative association between takeover premiums and the target firm pre-acquisition step-up and the reduction of this association after the adoption of IFRS occurs only for bidding firms which offer an accounting-based bonus plan to their CEOs.

\section{Research method}

The following model is estimated to test our hypotheses:

PREMIUM $_{i}=\alpha_{i}+\beta_{1}$ PRESTP $_{i}+\beta_{2}$ IFRS $_{i}+\beta_{3}$ PRESTPXIFRS $_{i}+\beta_{4}$ MULTIPLE $_{i}+$ $\beta_{5}$ FRIENDLY $_{i}+\beta_{6}$ CASHPAYT $_{i}+\beta_{7}$ TOEHOLD $_{i}+\beta_{8}$ TGTDIROWN $_{i}+\beta_{9}$ TGTROE $_{i}+$ $\beta_{10}$ TGTLEV $_{i}+\beta_{11}$ TGTSIZE $_{i}+\beta_{12}$ TGTFCF $_{i}+$ INDUSTRY $+\varepsilon_{i}$

The dependent variable (PREMIUM) is the takeover premium measured as the initial offer price minus the target share price two months prior to the takeover announcement, divided by 
the this share price. ${ }^{8}$ Consistent with prior studies (Nathan, 1988 and Ayers et al., 2002), the target firm's pre-acquisition step-up is approximated by subtracting the target firm book value of equity $\mathrm{t}$ the date of the financial statements provided before the takeover, from target firm market capitalisation measured two months before the takeover announcement, divided by the book value of equity (PRESTPEQ). This measure is used as the actual step-up is mechanically increased by the takeover premium. To minimise the possibility that our results are driven by scale effects, we also present results scaling PRESTP by average target firm assets over the two years before the takeover announcement (PRESTPASSETS). An indicator variable (IFRS) is set to one for takeovers announced during financial years in which the firm prepares financial statements using IFRS. To test $\mathrm{H}_{2}$ each measure of the target firm PRESTP is interacted with the IFRS indicator variable (PRESTPxIFRS).

The control variables in regression model (1a) are informed by previous research. Premiums are expected to increase with competing bidders for a target firm (e.g., Flanagan and O’Shaughnessy, 2003; Henry, 2005). Takeovers with multiple bidders are identified using an indicator variable (MULTIPLE). Takeover hostility has been documented to result in higher premiums (e.g., Bugeja and Walter, 1995; Franks and Mayer, 1996; Holl and Kyriazis, 1996). We measure the attitude of the target firm using an indicator variable coded as one if the initial target board recommendation is takeover acceptance (FRIENDLY). Previous research (e.g., Huang and Walkling, 1987; Kaufman, 1988; Bugeja and Da Silva Rosa, 2010) shows premiums are higher when cash consideration is offered because cash payment is immediately taxable. Method of payment is controlled in the regression model using an indicator variable denoting payment which is exclusively cash (CASHPAYT).

\footnotetext{
${ }^{8}$ If equity is offered as consideration, the bidding firm share price two months prior to the takeover announcement is used to calculate the value of the initial offer.
} 
Target firm ownership structure is also expected to affect premiums. A higher bidding firm toehold (TOEHOLD) in the target improves the bidder's bargaining position as it is necessary to acquire fewer shares and is expected to lower premiums (e.g., Stulz, 1988 and Stulz et al., 1990). The target firm bargaining position is greater when the target firm board owns a greater proportion of outstanding shares. As such, we include target firm board ownership as a control in the model and expect this variable to be positively associated with premiums (TGTDIROWN). An agency perspective however, suggests the opposite association since agency problems increase at low levels of target ownership. If takeovers are intended to solve target firm agency conflicts, then premiums are predicted to increase at lower levels of target board ownership (Manne, 1965; Fama, 1980).

Controls are also included for a number of target firm financial characteristics. Following Schwert (2000), we control for target firm performance using the return on equity ratio (TGTROE). Israel (1991) and Israel (1992) suggest that leverage is positively associated with premiums as highly levered firms have a more concentrated ownership structure. Target firm leverage is measured using the debt to equity ratio (TGTLEV). Target firm size influences the negotiating position of the target firm and as a result, premiums are predicted to increase with size (Moeller et al., 2004). Target size is measured using the natural logarithm of market capitalisation at the financial year end prior to the takeover announcement (TGTSIZE). Jensen (1986) suggests that takeovers which reduce the agency costs of free cash flow result in higher premiums. Free-cash flow is measured as cash flow from operations less dividends, divided by average total assets $(T G T F C F)$. Each of these financial variables is measured using information extracted from the most recent target firm financial statements prior to the takeover announcement. Information on whether the bidding firm compensates their CEO using an accounting-based bonus plan is manually collected from the annual report for the financial year before the takeover announcement. 
As an extension of model (1a), we also estimate regression model (1b) using only listed Australian bidders. This sample restriction allows us to include a number of bidding firm financial characteristics in the model. This expanded regression model is as follows:

PREMIUM $_{i}=\alpha_{i}+\beta_{1}$ PRESTP $_{i}+\beta_{2}$ IFRS $_{i}+\beta_{3}$ PRESTPXIFRS $_{i}+\beta_{4}$ MULTIPLE $_{i}+$ $\beta_{5}$ FRIENDLY $_{i}+\beta_{6}$ CASHPAYT $_{i}+\beta_{7}$ TOEHOLD $_{i}+\beta_{8}$ TGTDIROWN $_{i}+\beta_{9}$ TGTROE $_{i}+$ $\beta_{10}$ TGTLEV $_{i}+\beta_{11}$ TGTSIZE $_{i}+\beta_{12}$ TGTFCF $_{i}+\beta_{13}$ BIDMB $_{i}+\beta_{14}$ BIDDIROWN $_{i}+$ $\beta_{15} B_{I D R O E}+\beta_{16}$ BIDLEV $_{i}+\beta_{17}$ BIDSIZE $_{i}+\beta_{18}$ BIDFCF $_{i}+$ INDUSTRY $+\varepsilon_{i}$

Rau and Vermaelen (1998) find that glamour acquirers pay higher premiums and experience poorer post- merger performance. To control for this effect we include the bidding firm marketto-book $(B I D M B)$ ratio two months before the takeover announcement. We include the percentage ownership of the bidding firm board of directors at the time of the takeover announcement $(B I D D I R O W N)$. If bidders are more likely to overpay when they are subject to greater agency problems, then a negative association is predicted between this variable and premiums. Bidder performance and leverage are added to the model using, respectively, the return on equity (BIDROE) and debt-to-equity ratios (BIDLEV). Larger bidders have greater negotiating power suggesting a reduction in premiums. Jensen (1986) argues that bidders with free cash flow may be willing to undertake value destroying acquisitions thus predicting a positive association between free cash flow and premiums. Bidding firm size is measured as the natural logarithm of market capitalisation (BIDSIZE), whilst free cash flow is calculated as operating cash flows less dividends, divided by average total assets (BIDFCF). The previous four variables are measured using financial information collected from the most recent financial statements issued before the takeover announcement.

In both regression models ( $1 \mathrm{a}$ and $1 \mathrm{~b}$ ), standard errors are clustered by year and target industry. The models also include industry indicator variables to control for industry fixed effects based on the target firm two-digit GICS code. We do not control for year fixed effects because the year indicator variables are highly correlated with the IFRS indicator variable. 


\section{Sample and descriptive statistics}

The Connect 4 Mergers and Acquisitions Database is used to identify 942 takeovers for Australian publicly listed targets between 1997 and 2009. We exclude 340 takeovers for which the amount of PRESTP is negative. We do however, use this subset of firms as a control group for which we expect no change in premiums before and after the adoption of IFRS (see section $6.3)$.

To ensure that only bidders subject to Australian accounting standards are analysed, we removed 186 takeovers by bidders domiciled outside Australia. Finally, we excluded 36 takeovers for which there was insufficient data to estimate model (1a) leaving a sample of 380 . In the estimation of model (1b) we also exclude 64 takeovers announced by non-listed Australian bidders as it is not possible to obtain financial information for these firms. Panel A of Table 1 summarises the sample selection process.

\section{INSERT TABLE 1 HERE}

Panel B presents the temporal distribution of the sample. The highest numbers of takeovers are in 2006 and 2007. The period with the fewest takeovers are the first three years of the sample. Approximately 48\% of takeovers are announced between 1997 and 2004.

Financial data is hand collected from financial reports released for the one and two financial years immediately before the takeover announcement. Details on offer price, consideration form, the target firm board recommendation and ownership details of the bidder and target firm directors are manually extracted from takeover documents lodged with the Australian Securities Exchange. The Morningstar DatAnalysis Premium database is used to source takeover documents and target and bidder firm financial reports. Share price data is obtained from SIRCA’s Core Research Database. 
The existence of an accounting-based bonus plan for bidding firm CEOs is determined by manually checking the annual report for the year before the takeover. As some firms provided insufficient remuneration disclosures to identify whether a CEO bonus plan existed, we exclude 65 observations leaving a sample of 251 takeovers. Due to insufficient disclosure, we cannot determine if the CEOs remunerated with an accounting-based bonus plan are compensated using a measure of profit that includes or excludes amortisation charges. As a result, our classification scheme may be inaccurate and potentially biases us against finding a result. Furthermore, we cannot determine from disclosures whether bonuses are based on rolling GAAP. However, discussions with two remuneration consultants suggest that firms use rolling GAAP for the purposes of determining bonuses based on accounting performance.

Table 2 presents descriptive statistics for the variables included in the regression models. We also show means for each variable partitioned by whether the takeover was announced pre- or post- IFRS. Within our sample, $52 \%$ of bids are announced post- IFRS.

\section{INSERT TABLE 2 HERE}

Similar to prior research, target shareholders are offered large premiums which average approximately $30 \%$ (median is $16 \%$ ). The average pre-acquisition step-up is $529 \%$ of target's equity and $150 \%$ of target's average assets. As the median PRESTPEQ is only $111 \%$ of the book value of target equity, the distribution of PRESTPEQ is skewed. Although premiums and the pre-acquisition step-up are both higher subsequent to the adoption of IFRS, a $t$-test indicates that the differences are not statistically significant except for PRESTPASSETS. ${ }^{9}$

Accounting-based bonus plans (BONUS) are offered by $59 \%$ of bidding firms. Although the post-IFRS sample has a higher proportion of bidders using accounting based bonus

\footnotetext{
${ }^{9}$ A comparison of medians (unreported) before and after IFRS adoption is insignificant for PRESTPEQ. For PRESTPASSETS the median is significantly higher after the adoption of IFRS.
} 
compensation the difference to the pre- IFRS sample is insignificant. The majority of takeovers (i.e., 67\%) in the sample are friendly and exclusively cash payment is offered in $42 \%$ of bids. The median target return on equity and free cash flow are positive indicating that the majority of targets are not poorly performing. For bidding firms the average level of board ownership is $14 \%$ and the median return on equity is $11 \%$. After the adoption of IFRS, takeovers are less likely to have competing bidders and cash payment is used less frequently. Furthermore, target firm size, the bidding firm market-to-book ratio and bidding firm leverage are higher subsequent to the implementation of IFRS.

We calculate Pearson correlation coefficients between the dependent and (non-binary) independent variables included in the regression models, but in the interests of brevity do not present the results. The correlation between premiums and the pre-acquisition step-up are insignificant, whilst the correlation between PRESTPEQ and PRESTPASSETS is positive and significant (0.29). The correlations between the pre-acquisition step-up and the other independent variables are generally insignificant. The only exceptions are between PRESTPEQ and respectively TGTROE (-0.65) and TGTLEV (0.77). The size of the other significant correlations suggests that multicollinearity is not a problem with the estimation of model (1) (Gujarati 1995). This is confirmed by the calculation of VIF diagnostics after the estimation of each regression model.

\section{Results}

\subsection{Primary tests and findings}

Table 3 provides the results of estimating the regression models. The findings are presented separately for both the full sample and only listed bidders using alternatively the two different 
scalars of the step-up. ${ }^{10}$ The adjusted R-squared of the regressions range from $7 \%$ to $19 \%$, whilst the F-statistics indicate that each model is significant.

\section{INSERT TABLE 3 HERE}

The coefficient on both PRESTPEQ and PRESTPASSETS are negative and significant supporting $H_{1}$. To assess the economic significance of our findings we use the coefficients on the results in Table 3 and the descriptive statistics for the mean and median step-up reported in Table 2. For PRESTPEQ a move from the median (1.11) to the mean (5.29) implies a reduction in the premium of between 5.4\%-7.1\%. In comparison, for PRESTPASSETS a move from the median (0.59) to the mean (1.50) suggests a decline in the premium of between $2.3 \%-2.6 \%$. Consistent with $\mathrm{H}_{2}$, when we scale the pre-acquisition step-up by equity the coefficient on PRESTPXIFRS is positive and significant at $5 \%$ for the full sample and $1 \%$ for the sample of listed bidders. The coefficient on PRESTPXIFRS is also positive and significant when we scale PRESTP by average target firm assets, although the result is only significant at the $10 \%$ level for the full sample of takeovers. Overall our results suggest that the negative association between the pre-acquisition step-up of the target firm and premiums diminished once bidding firms were no longer required to amortise goodwill. It is notable that the coefficient on the IFRS indicator variable is insignificant indicating no change in premiums before and after 2005 after controlling for the interaction of IFRS with the pre-acquisition step-up. We once again assess the economic significance of our findings on PRESTPXIFRS using the mean and median pre-acquisition step-up. Our results suggest that a move from the median to mean PRESTPEQ or PRESTPASSETS respectively leads to a $4.6-6.7 \%$ or $2 \%-2.4 \%$ increase in the premium after the adoption of IFRS. ${ }^{11}$

\footnotetext{
${ }^{10}$ The number of observations is reduced when PRESTP is scaled by average assets as it was not possible to obtain the opening balance of assets for a number of target firms.

${ }^{11}$ As an additional test the models were estimated (results not reported) after excluding the interaction variable and the IFRS dummy. The coefficient on PRESTP was insignificant.
} 
A number of control variables report significant coefficients in Table 3. Premiums significantly increase with bidder firm size consistent with these bidders having access to greater resources. Target size is inversely associated with premiums similar to the results in Anderson, et al. (1994). Target firm leverage and ROE are positively associated with premiums when we use PRESTPEQ as the measure of the step-up. The result on target firm leverage is consistent with the findings in Israel (1992).

\subsection{Impact of bidding firm CEO compensation structure}

We predict that the association between takeover premiums and the target firm pre-acquisition step-up before and after Australia adopted IFRS differs for firms with and without an accounting-based CEO compensation plan. To test $H_{3}$, we partition the sample of listed bidders into firms with (144 firms) $(B O N U S=1)$ and without $(B O N U S=0)(107$ firms $)$ a CEO accounting-based bonus plan and estimate model 1(b) separately for the two groups. These results are presented in Table $4 .^{12}$

\section{INSERT TABLE 4 HERE}

Compared to Table 3, the results in Table 4 show increased explanatory power of the model with the adjusted R-squared ranging from $26.7 \%$ to $34.6 \%$. This is greater than that reported in both Robinson and Shane (1990) and Ayers et al. (2002). The F-statistics also indicate that the models are significant.

In takeovers where the bidding firm's CEO is not remunerated using an accounting-based bonus plan, the interaction term between PRESTP (both PRESTPEQ and PRESTPASSETS) and IFRS are insignificant indicating no change in this association after IFRS adoption. The coefficient on PRESTP is also insignificant. In contrast, the findings for takeovers in which the CEO has an accounting-based bonus plan are consistent with those presented in Table 3. Our

\footnotetext{
${ }^{12}$ Again the sample size is reduced when we scale PRESTP by average assets.
} 
results support prior research which documents the influence of the structure of management compensation plans on accounting choice and suggest that CEO accounting-based compensation, increases the risk of wealth transfers from bidding to target firm shareholders. The results in Table 4 show an increase in the number of significant control variables compared to Table 3. For example, better performing bidders $(R O E)$ pay significantly higher premiums. Similar to the findings in Table 3 target and bidder size are respectively negatively and positively associated with premiums. The positive association between the bidding firm market-to-book ratio and premiums is similar to that found in Rau and Vermaelen (1998). It is notable however, that when the bidder has an accounting-based CEO bonus plan in place, the bidder market-to-book ratio is negatively related to premiums. Inconsistent with earlier research (Stulz et al., 1990) a larger toehold is associated with higher premiums when the bidding CEO is compensated using an accounting-based bonus plan.

\subsection{Additional testing}

\subsubsection{Alternative interpretations on step-up}

A possible concern with our results is that since the pre-acquisition step-up approximates the market-to-book ratio there may be alternative explanations for our findings. Whilst we argue below that the theoretical validity of these alternative explanations does not appear as strong as the argument we have presented, we cannot completely rule them out.

\section{Accounting conservatism}

The market-to-book ratio has been used in prior research as a measure of conservatism (Wang et al., 2009). An alternative explanation for our findings, therefore, is that bidding firms pay lower premiums for targets with conservative accounting and this association weakened after 2005. Given the benefits of accounting conservatism documented in earlier studies, it seems unlikely that target firms with more conservative accounting are likely to be 'punished' through 
the payment of a lower premium. ${ }^{13}$. However, if we accept the argument that more conservative targets receive a lower premium, the weakening of this association post-IFRS would suggest that accounting became less conservative after Australia adopted IFRS. This is, however, inconsistent with the evidence in Lai et al. (2013a) who show that after Australia adopted IFRS, unconditional conservatism measured using a firm's market-to-book ratio increased.

To provide some evidence on whether our results are consistent with conservatism we follow Balakrishna et al. (2007) and Lai et al. (2013a) and use the frequency of target firm losses as a measure of conservatism. Specifically, we measure conservatism as the proportion of target firm earnings which are negative over the five years before the takeover (CONSERVATISM). We then estimate our regression models replacing PRESTP with CONSERVATISM. We find an insignificant association between premiums and our proxy for conservatism. Furthermore, the interaction term between CONSERVATISM and IFRS is also insignificant. These findings suggest that our results on PRESTP are not explained by conservatism.

\section{Target firm risky growth}

The market-to-book ratio has also been used as a measure of the risk in buying earnings growth (e.g., Penman and Reggiani, 2013). An alternative explanation for our results, therefore, is that bidding firms pay lower premiums for targets with risky growth opportunities perhaps due to the greater uncertainty associated with future growth. Whilst such an argument is plausible, it cannot explain why bidders would increase premiums for uncertain growth prospects post2005, particularly in light of the global financial crisis (GFC). In an attempt to assess if PRESTP is proxying for firm growth we replace the PRESTP variable in our regression analysis with target firm sales growth in the two years before the takeover announcement $(G R O W T H) .{ }^{14} \mathrm{We}$

\footnotetext{
${ }^{13}$ Some of these benefits include: a lower cost of debt (Ahmed et al., 2002; Zhang, 2008); higher corporate governance quality (Lara et al., 2009); more profitable acquisitions (Francis and Martin, 2010) and higher announcement returns to seasoned equity offerings (Kim et al., 2013).

${ }^{14}$ We use pre-takeover sales growth as a proxy for expected growth due to the unavailability of expected growth data. Wyatt (2005) for example uses industry level growth estimates provided by the Australian Bureau of Statistics (ABS) to proxy for earnings growth. However the ABS no longer collates this data.
} 
also interact this new variable with our IFRS dummy (GROWTHxIFRS). The results indicate that target firm sales growth is not significantly associated with premiums and suggest that our results on PRESTP are not explained by target firm growth.

\section{Tech bubble and the global financial crisis}

Finally, we test if our results are sensitive to the exclusion of certain sub-periods. For example, it could be argued that PRESTP proxies for firm overvaluation and that this measure was seen as a more reliable measure of overvaluation in the pre-IFRS period perhaps due to the "techbubble." In contrast, in the post- IFRS period, perhaps, due to the global financial crisis this measure no longer provided a credible signal of overvaluation. To test this possibility we reestimate our analysis by excluding alternately the "tech-bubble" years (i.e., 2000-2001) and the years affected by the global financial crisis (2008-2009). The interpretations from our findings are unchanged.

\subsubsection{Functional fixation on earnings}

Following the arguments from Hand (1990) (i.e., earnings functional fixation hypothesis), we test whether managers who adjust premiums for changes in the goodwill accounting rules are those who believe their investors are unsophisticated and thus less likely to 'see through' the effect of accounting rule changes. To conduct this analysis we partition our sample using median firm size into sophisticated (i.e., large firms) and unsophisticated firms (i.e., small firms) and repeat the analysis in Table 3. The results (not tabulated) are largely inconsistent with the functional fixation hypothesis. ${ }^{15}$

\subsubsection{Placebo tests}

\footnotetext{
${ }^{15}$ We also use median substantial shareholder ownership to partition into investor sophistication groups and obtain similar results. Additionally, we include blockholder ownership percentages and the number of blockholders alternatively in our regression models as an additional variable and find no significant association between both variables and premiums. The conclusions or our main test variables are unchanged.
} 
As described in Pope and Macleay (2011), researchers face an identification problem in attempting to attribute an observed outcome to the adoption of IFRS. We attempt to address the identification problem in a number of ways.

\section{Firms with a negative step-up}

First, we identify target firms for which our measure of the pre-acquisition step-up is negative. As accounting rules for a bargain purchase was not modified with IFRS adoption, we expect no change in the association between premiums and a bargain purchase pre- and post-IFRS. To test for such an effect we replace PRESTP in regression model (1) with the absolute value of any bargain purchase $(D I S C)$ scaled alternatively using the book value of equity $(D I S C E Q)$ and average assets (DISCASSETS). This bargain purchase measure is then interacted with the IFRS dummy (DISCxIFRS). The results (not tabulated) show an insignificant association between a bargain purchase and premiums. Importantly, the interaction term DISCXIFRS is also insignificant indicating that the association was unchanged after the adoption of IFRS.

\section{U.S. takeovers}

The second placebo test estimates model (1) using U.S. takeover data for publicly listed targets between 2002 and 2009. We start the sample from 2002 as this is the first full year which required the use of the purchase method in the U.S. Details of takeovers and the data requirements are obtained from SDC Platinum, Compustat and Corporate Library. The IFRS variable included in the regression is a notional IFRS dummy denoting takeovers announced from 2005 onwards. Table 5 presents the results.

\section{INSERT TABLE 5 HERE}

The findings show an insignificant coefficient on the interaction between the notional IFRS dummy and the measure of the target firm pre-takeover step-up. As there was no change in accounting method for goodwill in the U.S. in 2005, this insignificant result is unsurprising. 
More importantly these results provide additional confidence that the findings documented in this study for Australia are not explained by another confounding event.

\section{Loss making firms}

We also examine if our results are sensitive to whether the bidding firm is profit-making since CEOs of bidding firms making losses are likely to be less concerned as to the use of accounting numbers in compensation contracts. To undertake this analysis we re-estimate the analysis presented in Table 4 and replace BIDROE with an indicator variable denoting bidders making a loss in the year prior to the takeover announcement $(L O S S)$. We also interact this variable with the IFRS dummy (LOSSxIFRS). ${ }^{16}$ We find a negative association between LOSS and PREMIUM whilst the interaction between LOSS and IFRS is insignificant indicating loss firms did not alter their premiums after IFRS adoption. The conclusions from our main test variables are unchanged.

\subsubsection{Variation in industry takeover activity over time}

Prior research indicates that takeovers occur in waves and cluster across time within industry (Mitchell and Mulherin 1996; Harford 2005). We construct a merger and acquisition cycle variable calculated as the percentage of firms in the target firm's industry which receive a takeover offer in the year before the takeover announcement (M\&ACYCLE). We then repeat our analysis including this additional variable. The findings on $M \& A C Y C L E$ are insignificant in the regressions that include PRESTPEQ. In the regressions which include PRESTPASSETS, we find a negative association between takeover premiums and $M \& A C Y C L E$ consistent with the findings in Duong and Izan (2012). Importantly, the conclusions on our main findings are unchanged.

\footnotetext{
${ }^{16}$ Due to the small sample size we are unable to estimate our models after partitioning bidding firms which have a CEO bonus plan into those which are loss-making $(\mathrm{N}=14)$ and those which are profitable $(\mathrm{N}=113)$.
} 
As an additional test we compare the average step-up for each target firm industry (pre- and post- IFRS. We find a significant difference after IFRS for GICS code 15 (Materials) and GICS code 25 (Consumer discretionary). We re-estimate our regression models with the inclusion of an interaction term between the industry indicator variables for these two industries and the IFRS dummy. The coefficients on the industry indicator variables and the new interaction variables are insignificant. Our main findings remain unchanged.

\subsubsection{Other tests}

Goodwin et al., (2008) discuss the main changes to Australian GAAP upon the adoption of IFRS. In relation to the accounting for takeovers, the most pertinent non-goodwill change was in regards to identifiable intangible assets. ${ }^{17}$ Prior to 2005 there was no accounting standard for identifiable intangible assets (other than research and development). Subsequent to IFRS adoption, AASB 138 required the recognition of purchased identifiable intangibles and the amortisation of such assets with a finite life. AASB 138 prohibited the recognition of internally developed intangibles. ${ }^{18}$ To empirically test for an association between target firm intangible assets and premiums we manually collect the amount of intangible assets recognised in each successful takeover. ${ }^{19} \mathrm{We}$ construct a dummy variable equal to one (IIA_DUMMY) if a bidder recognises intangible assets and zero otherwise. We also interact this dummy variable with the IFRS dummy (IIA_DUMMYXIFRS). We then re-estimate model (1) with the inclusion of these additional two variables. The coefficients on both additional variables are insignificant. Furthermore, the main findings of our paper remain unchanged. ${ }^{20}$

\footnotetext{
${ }^{17}$ Although, the adoption of IFRS altered the accounting rules in many other areas, these changes had no direct impact on the accounting for business combinations. We do not believe these other changes explain our results. 18 The exception is development expenditure which can be recognised if strict conditions are met.

${ }^{19}$ It is necessary to use the amount of intangible assets recorded after the acquisition as not all intangible assets appear on the target firm balance sheet (e.g., internally generated intangible assets). A weakness with our approach is that the allocation of the purchase price across asset types is subject to managerial discretion. ${ }^{20} \mathrm{We}$ also conduct this analysis using the amount of identifiable intangible assets recorded in the acquisition scaled by target firm assets instead of the IIA_DUMMY variable. Our main findings remain unchanged.
} 
To examine whether existing bidding firm goodwill influences premiums we re-estimated our models including an indicator variable for bidders with a non-zero goodwill balance. The coefficient on this additional variable is insignificant and the results for our test variables of interest are unchanged. To assess if outliers impact our findings, we repeat our analysis using rank-regression and after winsorising the top and bottom $1 \%$ of our continuous variables. The conclusions from our findings are similar to those presented. The conclusion from our results are also unchanged if we calculate premiums using the target share price one month or ten days before the announcement date.

It may be contended that our premise that target firms with a higher step-up receive lower premiums is unrealistic as it ignores the need for target firm cooperation to achieve takeover success. $^{21}$ To empirically examine this contention, we estimate a logit regression with alternatively a successful takeover outcome or takeover hostility as the dependent variable. The independent variables in these models are identical to those in regression model 1 except that FRIENDLY is excluded in the model of takeover hostility as it is now used as the dependent variable. The results for these models (not reported) show no association between both takeover hostility and takeover outcome and the target firm pre-acquisition step-up. Furthermore, this association is unaltered after the adoption of IFRS.

Table 2 shows a number of control variables report significant differences after IFRS. To examine if the association between these controls and premiums varies across time, we reestimate our models (alternately for each significant control) after including an interaction variable between each control and the IFRS dummy. We find a negative association between MULTIPLEXIFRS and premiums, whilst the other interaction variables are insignificant. The conclusions on the main findings are unchanged.

\footnotetext{
${ }^{21}$ As this line of argument indicates that takeovers of firms with a higher pre-acquisition step-up are more likely to fail, it supports our research method of including all takeovers in the analysis irrespective of deal outcome.
} 


\section{Conclusions}

This study examines the association between takeover premiums and the target firm preacquisition step-up. Our results show a negative association between premiums and the preacquisition step-up with this association decreasing after IFRS adoption. These findings suggest that when a greater proportion of the step-up is required to be expensed, bidders pay less for targets with a higher step-up prior to the acquisition to avoid a further reduction in postacquisition profit. However, after the adoption of IFRS, when goodwill is no longer amortised, this discounting of premiums for targets with a higher pre-acquisition step-up no longer occurs. We also document that the change in the association between premiums and the target firm pre-acquisition step-up post- IFRS holds only for bidders which offer an accounting-based performance plan to their CEOs prior to the takeover announcement. Our findings are therefore consistent with an unintended consequence of Australia's adoption of IFRS, being an increase in premiums for target firms with a larger step-up. These findings add to the CEO compensation literature by showing that the structure of the CEO compensation can have unintended consequences following a change in accounting standards.

A caveat regarding the results in this study is the possibility that a change in an omitted variable occurring at the same time as IFRS adoption explains our results. While the additional testing we conduct suggests that this is not the case, the possibility that a confounding event drives our results must be acknowledged. Future research could extend our study to examine whether managers exercise discretion in the allocation of the purchase price across different assets acquired in a business combination, and whether the exercise of this discretion changed upon Australia's adoption of IFRS. 


\section{References}

Aboody D, Kasznik R and Williams M (2000) Purchase versus pooling in stock-for-stock acquisitions: Why do firms care? Journal of Accounting and Economics 29: 261-286.

Accounting Principles Board (1970) Accounting Principles Board Opinion 16 Business Combinations, New York, United States of America.

Accounting Standards Board (1997) Financial Reporting Standard 10 Goodwill and Intangible Assets, London, United Kingdom.

Accounting Standards Committee (1984) Statement of Standard Accounting Practice 22 Accounting for Goodwill, London, United Kingdom.

Ahmed A, Billings B, Morton R, et al. (2002) The role of accounting conservatism in mitigating bondholder-shareholder conflicts over dividend policy and in reducing debt costs. The Accounting Review 77: 867-890.

Anderson D, Haynes A and Heaney R (1994) Company takeover and equity returns: The target size effect. Australian Journal of Management 19: 1-30.

Anderson D and Zimmer I (1992) Reactions to regulation of accounting for goodwill. Accounting and Finance 32: 27-50.

Armstrong C, Guay W and Weber J (2010) The role of information and financial reporting in corporate governance and debt contracting. Journal of Accounting and Economics 50: 179234.

Australian Accounting Standards Board (1988) AASB 1013 Accounting for Goodwill, Melbourne, Australia.

Australian Accounting Standards Board (2004) AASB 136 Impairment of Assets, Melbourne, Australia.

Australian Accounting Standards Board (2004) AASB 138 Intangible Assets, Melbourne, Australia.

Ayers B, Lefanowicz C and Robinson J (2000) The effects of goodwill tax deductions on the market for corporate acquisitions. The Journal of the American Taxation Association 22: 3450.

Ayers B, Lefanowicz C and Robinson J (2002) Do firms purchase the pooling method? Review of Accounting Studies 7: 5-32.

Balakrishna H, Coulton J and Taylor S (2007) Accounting losses and earnings conservatism: evidence from Australian generally accepted accounting principles. Accounting and Finance 47: 381-400. 
Barth M, Landsman W and Lang M (2008) International accounting standards and accounting quality. Journal of Accounting Research 46: 467-498.

Bates T and Lemmon M (2003) Breaking up is hard to do? An analysis of termination fee provisions and merger outcomes. Journal of Financial Economics 69: 469-504.

Beatty A and Weber J (2006) Accounting discretion in fair value estimates: An examination of SFAS 142 goodwill impairments. Journal of Accounting Research 44: 257-288.

Bebchuk L and Fried J (2005) Pay without performance: Overview of the issues. Journal of Corporation Law 30: 647-673.

Beneish M (1999) Incentives and penalties related to earnings overstatements that violate GAAP. The Accounting Review 34: 425-457.

Brochet F, Jagolinzer A and Riedl E (2013) Mandatory IFRS adoption and financial statement comparability. Contemporary Accounting Research 30: 1373-1400.

Bugeja M and Da Silva Rosa R (2010) Capital gains taxation and shareholder wealth in takeovers. Accounting and Finance 50: 241-262.

Bugeja M and Walter T (1995) An empirical analysis of some determinants of the target shareholder premium in takeovers. Accounting and Finance 35: 33-60.

Chalmers K, Clinch G and Godfrey J (2011a) Changes in value relevance of accounting information upon IFRS adoption: Evidence from Australia. Australian Journal of Management 36: 151-173.

Chalmers K, Godfrey J and Webster J (2011b) Does a goodwill impairment regime better reflect the underlying economic attributes of goodwill? Accounting and Finance 51: 634-660. Chalmers, K, Clinch G, Godfrey J, et al. (2012) Intangible assets, IFRS and analysts' earnings forecasts. Accounting and Finance 52: 691-721.

Chapple L, Christensen B and Clarkson P (2007) Termination fees in a 'bright line' jurisdiction. Accounting and Finance 47: 643-665.

Choi F and Lee C (1991) Merger premia and national differences in accounting for goodwill. Journal of International Financial Management and Accounting 3: 219-240.

Clinch G (1995) Capital markets research and the goodwill debate. Australian Accounting Review 5: 22-30.

Copeland R and Wojdak J (1969) Income manipulation and the purchase-pooling choice. Journal of Accounting Research 7: 188-195.

Cotter J, Tarca A and Wee M (2012) IFRS adoption and analysts' earnings forecasts: Australian evidence. Accounting and Finance 52: 395-419. 
Da Silva Rosa R, Izan H, Steinback A, et al. (2000) The method of payment decision in Australian takeovers: An investigation of causes and consequences. Australian Journal of Management 25: 67-94.

Darrough M, Guler L and Wang P (2014) Goodwill impairment losses and CEO compensation. Journal of Accounting, Auditing and Finance 29: 435-463.

Draper P and Paudyal K (1999) Corporate takeovers: Mode of payment, returns and trading activity. Journal of Business Finance \& Accounting 26: 521-558.

Duong L and Izan H (2012) Consequences of riding takeover waves: Australian evidence. International Review of Finance 12: 399-434.

Fama E (1980) Agency problems and the theory of the firm. The Journal of Political Economy 88: 288-307.

Fields T, Lys T and Vincent L (2001) Empirical research on accounting choice. Journal of Accounting and Economics 31: 255-307.

Financial Accounting Standards Board (2001) SFAS 141 Business Combinations, Norwalk, United States of America.

Financial Accounting Standards Board (2001) SFAS 142 Goodwill and other intangible assets, Norwalk, United States of America.

Flanagan D and O'Shaughnessy K (2003) Core-related acquisitions, multiple bidders and tender offer premiums. Journal of Business Research 56: 573-585.

Francis J and Martin X (2010) Acquisition profitability and timely loss recognition. Journal of Accounting and Economics 49: 161-178.

Franks J and Mayer C (1996) Hostile Takeovers and the correction of managerial failure. Journal of Financial Economics 40: 163-181.

Gagnon J (1967) Purchase versus pooling of interests: The search for a predictor. Journal of Accounting Research 5: 187-204.

Gibson R and Francis J (1975) Accounting for goodwill - A study in permissiveness. Abacus 11: $167-171$.

Goodwin J, Ahmed K and Heaney R (2008) The effects of International Financial Reporting Standards on the accounts and accounting quality of Australian firms: A retrospective study. Journal of Contemporary Accounting and Economics 4: 89-119.

Gore P, Taib F and Taylor P (2000) Accounting for goodwill: an examination of factors influencing management preferences. Accounting and Business Research 30: 213-225.

Gujarati D (1995) Basic Econometrics ( $3^{\text {rd }}$ ed.). Sydney: McGraw-Hill. 
Hand J (1990) A test of the extended functional fixation hypothesis. The Accounting Review 65: $740-763$.

Harford J (2005) What Drives Merger Waves. Journal of Financial Economics 77: 529-60.

Henry D (2005) Directors' recommendations in takeovers: An agency and governance analysis. Journal of Business Finance \& Accounting 32: 129-159.

Holl P and Kyriazis D (1996) The determinants of outcome in UK takeover bids. International Journal of the Economics of Business 3: 165-184.

Huang Y and Walkling R (1987) Target abnormal returns associated with acquisitions announcements: payment, acquisitions form, and managerial resistance. Journal of Financial Economics 19: 329-349.

Israel R (1991) Capital structure and the market for corporate control: The defensive role of debt financing. The Journal of Finance 46: 1391-1409.

Israel R (1992) Capital and ownership structures, and the market for corporate control. Review of Financial Studies 5: 181-198.

James K, How J and Verhoeven P (2008) Did the goodwill accounting standard impose material economic consequences on Australian acquirers? Accounting and Finance 48: 625647.

Jensen M (1986) Agency costs of free cash flow, corporate finance and takeovers. American Economic Review 76: 323-329.

Kaufman D (1988) Factors affecting the magnitude of premiums paid to target firm shareholders in corporate acquisitions. The Financial Review 23: 465-482.

Kim Y, Li S, Pan C, et al. (2013) The role of accounting conservatism in the equity market: Evidence from seasoned equity offerings. The Accounting Review 88: 1327-1356.

Lai C, Lu M and Shan Y (2013a) Has Australian financial reporting become more conservative over time? Accounting and Finance 53: 731-761.

Lai C, Shan Y and Taylor S (2013b) Costs of mandatory international financial reporting standards. Australian Journal of Management 38: 491-521.

Lara J, Osma B and Penalva F (2009) Accounting conservatism and corporate governance. Review of Accounting Studies 14: 161-201.

Lee C and Choi F (1992) Effects of alternative goodwill treatments on merger premia: Further empirical evidence. Journal of International Financial Management and Accounting 4: 220236.

Manne H (1965) Mergers and the market for corporate control. The Journal of Political Economy 73: 110-120. 
Miller M (1995) Goodwill discontent: The meshing of Australian and international accounting policy. Australian Accounting Review 5: 3-16.

Mitchell M and Mulherin J (1996) The Impact of Industry Shocks on Takeover and Restructuring Activity, Journal of Financial Economics 41: 193-229.

Moeller S, Schlingemann F and Stulz R (2004) Firm size and the gains from acquisitions. Journal of Financial Economics 73: 201-228.

Nathan K (1988) Do firms pay to pool? Some empirical evidence. Journal of Accounting and Public Policy 7: 185-200.

Penman S and Reggiani F (2013) Returns to buying earnings and book value: Accounting for growth and risk. Review of Accounting Studies 18: 1021-1049.

Pope P and McLeay S (2011) The European IFRS experiment: Objectives, research challenges and some early evidence. Accounting and Business Research 41: 233-266.

Porter I (1994) New blast at goodwill standard. The Australian Financial Review: October 20, 26.

Ramanna K (2008) The implications of unverifiable fair-value accounting: Evidence from the political economy of goodwill accounting. Journal of Accounting and Economics 45: 253-281. Rau P and Vermaelen T (1998) Glamour, value and the post-acquisition performance of acquiring firms. Journal of Financial Economics 49: 223-253.

Robinson J and Shane P (1990) Acquisition accounting method and bid premia for target firms. The Accounting Review 65: 25-48.

Roll R (1986) The hubris hypothesis of corporate takeovers. Journal of Business 59: 197216.

Schwert G (2000) Hostility in takeovers: In the eyes of the beholder? The Journal of Finance 55: 2599-2640.

Shalev R, Zhang I and Zhang Y (2013) CEO compensation and fair value accounting: Evidence from purchase price allocation. Journal of Accounting Research 51: 819-854.

Stulz R (1988) Managerial control of voting rights: financing policies and the market forcorporate control. Journal of Financial Economics 20: 25-54.

Stulz R, Walkling R and Song M (1990) The distribution of target ownership and the division of gains in successful takeovers. The Journal of Finance 45: 817-833.

Wang R, Hogartaigh C and Van Zijl T (2009) Measures of accounting conservatism: A construct validity perspective. Journal of Accounting Literature: 165-203.

Wyatt A (2005) Accounting recognition of intangible assets: Theory and evidence on economic determinants. The Accounting Review 80: 967-1003. 
Zhang J (2008) The contracting benefits of accounting conservatism to lenders and borrowers. Journal of Accounting and Economics 45: 27-54. 
Panel A: Sample Selection

Takeovers between 1997 and 2009 on the Connect 4 Mergers and Acquisitions database

Exclusions:

Target firms with a negative step-up

Firms reporting with non-Australian GAAP

Missing data for regression model

Total sample size to estimate model (1a)

Bidder firms non-listed

Panel B: Distribution of takeovers by year

\begin{tabular}{llll} 
Year & Number & Proportion & $\begin{array}{l}\text { Cumulative } \\
\text { Proportion }\end{array}$ \\
\hline 1997 & 18 & 4.74 & 4.74 \\
1998 & 18 & 4.74 & 9.48 \\
1999 & 19 & 5.00 & 14.48 \\
2000 & 24 & 6.32 & 20.80 \\
2001 & 23 & 6.05 & 26.85 \\
2002 & 20 & 5.26 & 32.11 \\
2003 & 25 & 6.58 & 38.69 \\
2004 & 35 & 9.21 & 47.90 \\
2005 & 31 & 8.16 & 56.06 \\
2006 & 53 & 13.95 & 70.01 \\
2007 & 60 & 15.79 & 85.80 \\
2008 & 31 & 8.16 & 93.96 \\
2009 & $\underline{23}$ & $\underline{6.05}$ & 100.00 \\
Total & 380 & $100 \%$ & \\
\hline
\end{tabular}




\section{Table 2 Descriptive statistics}

This table presents descriptive statistics for the variables in the regression models for the entire sample and separately pre- and post- IFRS. A test of statistical difference before and after the adoption of IFRS for each variable is also shown. A $t$-test is used for continuous variables and a $\chi^{2}$-test for binary variables. PREMIUM is the takeover premium calculated as the offer price minus the target share price two months before the takeover announcement, divided by the target share price two months before the takeover announcement; PRESTPEQ is the target firm market value of equity two months before the takeover announcement minus the book value of equity, divided by the book value of equity; PRESTPASSETS is the target firm market value of equity two months before the takeover announcement minus the book value of equity, divided by average assets; IFRS is an indicator variable denoting takeovers announced after Australia adopted IFRS; MULTIPLE is an indicator variable set to 1 if there are multiple bidders for the target firm; FRIENDLY is an indicator variable set to 1 if the initial recommendation of the target firm board of directors is to accept the takeover offer; CASHPAYT is an indicator variable set to 1 if the payment form is exclusively cash; TOEHOLD is the ownership interest of the bidding firm in the target at the announcement of the takeover; TGTDIROWN is the percentage ownership of the target board of directors; TGTROE is the return on equity ratio of the target firm; TGTLEV is the debt-to-equity ratio of the target firm; TGTSIZE is the natural logarithm of market capitalisation of the target firm, and TGTFCF is free cash flow of the target firm scaled by average total assets; BIDMB is the market-to-book ratio of the bidding firm; BIDDIROWN is the percentage ownership of the bidder's board of directors; BIDROE is the return on equity ratio of the bidding firm; $B I D L E V$ is the debt-to-equity ratio of the bidding firm; BIDSIZE is the natural logarithm of market capitalisation of the bidding firm; and BIDFCF is free cash flow of the bidding firm scaled by average total assets. BONUS is a dummy variable coded as one for bidding firms which compensate their CEO using an accounting-based bonus plan in the year before the takeover announcement. All accounting variables are collected from the financial statements released before the takeover announcement.

\begin{tabular}{llllllll}
\hline Variable & $\mathrm{N}$ & Mean & Median & Std dev & Pre-IFRS & Post-IFRS & Stat diff \\
\hline PREMIUM & 380 & 0.299 & 0.162 & 1.758 & 0.214 & 0.378 & -0.94 \\
PRESTPEQ & 380 & 5.291 & 1.107 & 31.033 & 3.661 & 6.790 & -1.01 \\
PRESTPASSETS & 377 & 1.503 & 0.591 & 0.171 & 1.079 & 1.887 & $-2.37 * *$ \\
IFRS & 380 & 0.521 & 1.000 & 0.500 & - & - & - \\
MULTIPLE & 380 & 0.190 & 0.000 & 0.392 & 0.224 & 0.157 & $1.68 *$ \\
FRIENDLY & 380 & 0.668 & 1.000 & 0.471 & 0.639 & 0.692 & -1.09 \\
CASHPAYT & 380 & 0.416 & 0.000 & 0.494 & 0.470 & 0.364 & $2.10^{* *}$ \\
TOEHOLD & 380 & 0.118 & 0.002 & 0.176 & 0.128 & 0.109 & 1.06 \\
TGTDIROWN & 380 & 0.109 & 0.025 & 0.167 & 0.095 & 0.122 & -1.57 \\
TGTROE & 380 & -0.097 & 0.076 & 0.826 & -0.056 & -0.133 & 0.92 \\
TGTLEV & 380 & 2.648 & 0.809 & 12.874 & 2.215 & 3.046 & -0.62 \\
TGTSIZE & 380 & 18.562 & 18.482 & 1.960 & 18.238 & 18.866 & $-3.21 * * *$ \\
TGTFCF & 380 & -0.035 & 0.000 & 0.223 & -0.031 & -0.038 & 0.28 \\
BIDMB & 316 & 3.539 & 2.135 & 6.376 & 2.504 & 4.485 & $-2.91 * * *$ \\
BIDDIROWN & 316 & 0.136 & 0.051 & 0.181 & 0.143 & 0.124 & 1.16 \\
BIDROE & 316 & -0.002 & 0.114 & 1.632 & 0.104 & -0.098 & 1.16 \\
BIDLEV & 316 & 1.858 & 0.834 & 4.246 & 1.143 & 2.538 & $-3.07^{* * *}$ \\
BIDSIZE & 316 & 19.926 & 19.919 & 2.403 & 19.703 & 20.129 & -1.59 \\
BIDFCF & 316 & 0.143 & 0.046 & 1.873 & 0.056 & 0.222 & -0.78 \\
BONUS & 251 & 0.591 & 1.000 & 0.493 & 0.559 & 0.613 & -0.38 \\
\hline *** Sigifican
\end{tabular}

\footnotetext{
*** Significant at the $1 \%$ level $* *$ Significant at the $5 \%$ level $*$ Significant at the $10 \%$ level
} 
Table 3 Regression results of $\mathrm{H}_{1}$ and $\mathrm{H}_{2}$

This table presents the results of estimating the regression models where PREMIUM is the takeover premium calculated as the offer price minus the target share price two months before the takeover announcement, divided by the target share price two months before the takeover announcement; PRESTP is measured as (i) PRESTPEO which is the target firm market value of equity two months before the takeover announcement minus the book value of equity, divided by the book value of equity and (ii) PRESTPASSETS which is the target firm market value of equity two months before the takeover announcement minus the book value of equity, divided by average assets; IFRS is an indicator variable denoting takeovers announced after Australia adopted IFRS; PRESTPxIFRS is an interaction variable between PRESTP and IFRS; MULTIPLE is an indicator variable set to 1 if there are multiple bidders for the target firm; FRIENDLY is an indicator variable set to 1 if the initial recommendation of the target firm board of directors is to accept the takeover offer; CASHPAYT is an indicator variable set to 1 if the payment form is exclusively cash; TOEHOLD is the ownership interest of the bidding firm in the target at the announcement of the takeover; TGTDIROWN is the percentage ownership of the target board of directors; TGTROE is the return on equity ratio of the target firm; TGTLEV is the debt-to-equity ratio of the target firm; TGTSIZE is the natural logarithm of the market capitalisation of the target firm, and TGTFCF is free cash flow of the target firm scaled by average total assets; BIDMB is the market-to-book ratio of the bidding firm; BIDDIROWN is the percentage ownership of the bidder's board of directors; $B I D R O E$ is the return on equity ratio of the bidding firm; BIDLEV is the debt-to-equity ratio of the bidding firm; BIDSIZE is the natural logarithm of market capitalisation of the bidding firm; and $B I D F C F$ is free cash flow of the bidding firm scaled by average total assets. All accounting variables are collected from the financial statements released before the takeover announcement. Standard errors are clustered by year and target firm industry. Industry fixed effects are included in each model but results are not reported.

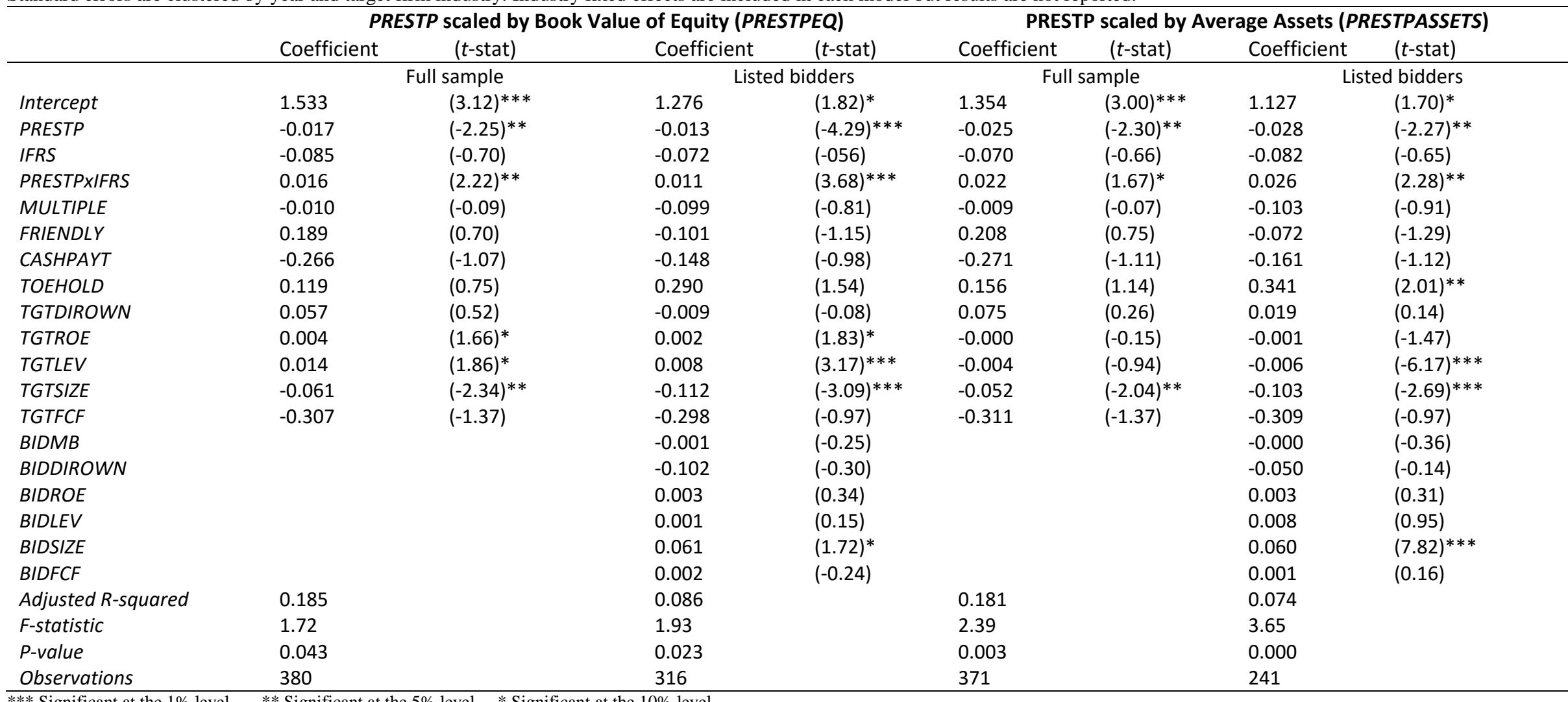

*** Significant at the $1 \%$ level $\quad * *$ Significant at the $5 \%$ level $*$ Significant at the $10 \%$ level 
Table 4 Regression results testing $H_{3}$ for firms with and without a bonus plan

This table presents the results of estimating the regression models for bidders with and without accounting-based bonus plans. PREMIUM is the takeover premium calculated as the offer price minus the target share price two months before the takeover announcement, divided by the target share price two months before the takeover announcement; PRESTP is measured as (i) PRESTPEQ which is the target firm market value of equity two months before the takeover announcement minus the book value of equity, divided by the book value of equity and (ii) PRESTPASSETS which is the target firm market value of equity two months before the takeover announcement minus the book value of equity, divided by average assets; IFRS is an indicator variable denoting takeovers announced after Australia adopted IFRS; PRESTPxIFRS is an interaction variable between PRESTP and IFRS; MULTIPLE is an indicator variable set to 1 if there are multiple bidders for the target firm; FRIENDLY is an indicator variable set to 1 if the initial recommendation of the target firm board of directors is to accept the takeover offer; $C A S H P A Y T$ is an indicator variable set to 1 if the payment form is exclusively cash; TOEHOLD is the ownership interest of the bidding firm in the target at the announcement of the takeover; TGTDIROWN is the percentage ownership of the target board of directors; TGTROE is the return on equity ratio of the target firm; TGTLEV is the debt-to-equity ratio of the target firm; TGTSIZE is the natural logarithm of the market capitalisation of the target firm, and TGTFCF is free cash flow of the target firm scaled by average total assets; BIDMB is the market-to-book ratio of the bidding firm; BIDDIROWN is the percentage ownership of the bidder's board of directors; BIDROE is the return on equity ratio of the bidding firm; BIDLEV is the debt-to-equity ratio of the bidding firm; BIDSIZE is the natural logarithm of market capitalisation of the bidding firm; and BIDFCF is free cash flow of the bidding firm scaled by average total assets. All accounting variables are collected from the financial statements released before the takeover announcement. Standard errors are clustered by year and target firm industry. Industry fixed effects are included in each model but results are not reported.

\begin{tabular}{|c|c|c|c|c|c|c|c|c|}
\hline \multirow[b]{3}{*}{ Variables } & \multicolumn{4}{|c|}{ PRESTP scaled by Book Value of Equity (PRESTPEQ) } & \multicolumn{4}{|c|}{ PRESTP scaled by Average Assets (PRESTPASSETS) } \\
\hline & \multicolumn{2}{|c|}{ BONUS $=0$} & \multicolumn{2}{|c|}{ BONUS = 1} & \multicolumn{2}{|c|}{ BONUS $=0$} & \multicolumn{2}{|c|}{ BONUS $=1$} \\
\hline & Coefficient & (t-stat) & Coefficient & (t-stat) & Coefficient & (t-stat) & Coefficient & (t-stat) \\
\hline Intercept & 0.365 & (0.59) & 0.194 & $(0.37)$ & 0.688 & (1.48) & 0.472 & $(0.98)$ \\
\hline PRESTP & 0.020 & (1.50) & -0.023 & $(-7.82)^{* * *}$ & 0.016 & $(0.41)$ & -0.210 & $(-2.74)^{* * *}$ \\
\hline IFRS & 0.150 & $(1.93)^{*}$ & 0.081 & $(1.22)$ & 0.022 & $(0.17)$ & -0.029 & $(-0.22)$ \\
\hline PRESTPXIFRS & -0.036 & $(-1.20)$ & 0.022 & $(8.05)^{* * *}$ & 0.009 & $(0.21)$ & 0.207 & $(2.60)^{* *}$ \\
\hline MULTIPLE & -0.053 & $(-0.55)$ & 0.056 & $(0.61)$ & -0.041 & $(-0.43)$ & 0.122 & (0.99) \\
\hline FRIENDLY & -0.027 & $(-0.33)$ & 0.024 & (0.36) & -0.051 & $(-0.76)$ & 0.025 & $(0.40)$ \\
\hline CASHPAYT & -0.117 & $(-1.11)$ & -0.046 & $(-0.35)$ & -0.087 & $(-0.72)$ & -0.056 & $(-0.48)$ \\
\hline TOEHOLD & -0.066 & $(0.36)$ & 0.568 & $(2.53)^{* *}$ & 0.126 & $(0.51)$ & 0.599 & $(2.01)^{* *}$ \\
\hline TGTDIROWN & -0.207 & $(-1.25)$ & 0.151 & $(5.53)^{* * *}$ & -0.252 & $(-0.87)$ & 0.024 & (1.01) \\
\hline TGTROE & -0.009 & $(-2.75)^{* * *}$ & 0.095 & $(2.21)^{* *}$ & 0.004 & $(0.86)$ & 0.121 & $(3.45)^{* * *}$ \\
\hline TGTLEV & 0.015 & $(0.57)$ & 0.008 & $(1.70)^{*}$ & 0.014 & $(0.81)$ & 0.003 & $(1.25)$ \\
\hline TGTSIZE & -0.059 & $(-1.41)$ & -0.078 & $(-2.76)^{* * *}$ & -0.063 & $(-1.84)^{*}$ & -0.090 & $(-2.77)^{* * *}$ \\
\hline TGTFCF & -0.030 & $(-0.31)$ & -0.016 & $(-0.15)$ & -0.078 & $(-0.76)$ & 0.057 & $(0.41)$ \\
\hline$B I D M B$ & 0.014 & $(2.13)^{* *}$ & -0.001 & $(-2.51)^{* * *}$ & 0.013 & $(2.03)^{* *}$ & -0.000 & $(-3.66)^{* * *}$ \\
\hline BIDDIROWN & 0.100 & $(0.34)$ & -0.290 & $(-1.24)$ & 0.102 & (0.38) & -0.458 & $(-1.47)$ \\
\hline BIDROE & 0.121 & $(3.55)^{* * *}$ & 0.016 & $(2.50)^{* *}$ & 0.095 & $(3.70)^{* * *}$ & 0.012 & $(4.33)^{* * *}$ \\
\hline BIDLEV & -0.032 & $(-1.34)$ & -0.006 & $(-1.10)$ & -0.025 & $(-1.36)$ & 0.004 & $(0.06)$ \\
\hline BIDSIZE & 0.053 & $(2.18)^{* *}$ & 0.068 & $(2.24)^{* *}$ & 0.043 & (1.41) & 0.068 & $(2.35)^{* *}$ \\
\hline BIDFCF & -0.093 & $(-0.27)$ & 0.005 & $(0.98)$ & -0.101 & $(-0.74)$ & -0.002 & $(-0.34)$ \\
\hline Adjusted R-squared & 0.267 & & 0.274 & & 0.272 & & 0.346 & \\
\hline F-statistics & 9.27 & & 66.63 & & 8.99 & & 327.14 & \\
\hline P-value & 0.000 & & 0.000 & & 0.000 & & 0.000 & \\
\hline Observations & 107 & & 144 & & 89 & & 117 & \\
\hline
\end{tabular}


Table 5 Regression results using a sample of US takeovers

This table presents the results of estimating regression model 1(b) using a sample of US takeovers. PREMIUM is the takeover premium calculated as the offer price minus the target share price two months before the takeover announcement, divided by the target share price two months before the takeover announcement; PRESTP is measured as (i) PRESTPEQ which is the target firm market value of equity two months before the takeover announcement minus the book value of equity, divided by the book value of equity and (ii) PRESTPASSETS which is the target firm market value of equity two months before the takeover announcement minus the book value of equity, divided by average assets; IFRS is an indicator variable denoting takeovers announced after Australia adopted IFRS; PRESTPxIFRS is an interaction variable between PRESTP and IFRS; MULTIPLE is an indicator variable set to 1 if there are multiple bidders for the target firm; FRIENDLY is an indicator variable set to 1 if the initial recommendation of the target firm board of directors is to accept the takeover offer; CASHPAYT is an indicator variable set to 1 if the payment form is exclusively cash TOEHOLD is the ownership interest of the bidding firm in the target at the announcement of the takeover; TGTDIROWN is the percentage ownership of the target board of directors; TGTROE is the return on equity ratio of the target firm; TGTLEV is the debt-to-equity ratio of the target firm; TGTSIZE is the natural logarithm of the market capitalisation of the target firm, and TGTFCF is free cash flow of the target firm scaled by average total assets; BIDMB is the market-to-book ratio of the bidding firm; BIDDIROWN is the percentage ownership of the bidder's board of directors; $B I D R O E$ is the return on equity ratio of the bidding firm; BIDLEV is the debt-to-equity ratio of the bidding firm; BIDSIZE is the natural logarithm of market capitalisation of the bidding firm; and $B I D F C F$ is free cash flow of the bidding firm scaled by average total assets. All accounting variables are collected from the financial statements released before the takeover announcement. Industry fixed effects are included in each model but results are not reported.

\section{PRESTP scaled by Book Value of Equity (PRESTPEQ)}

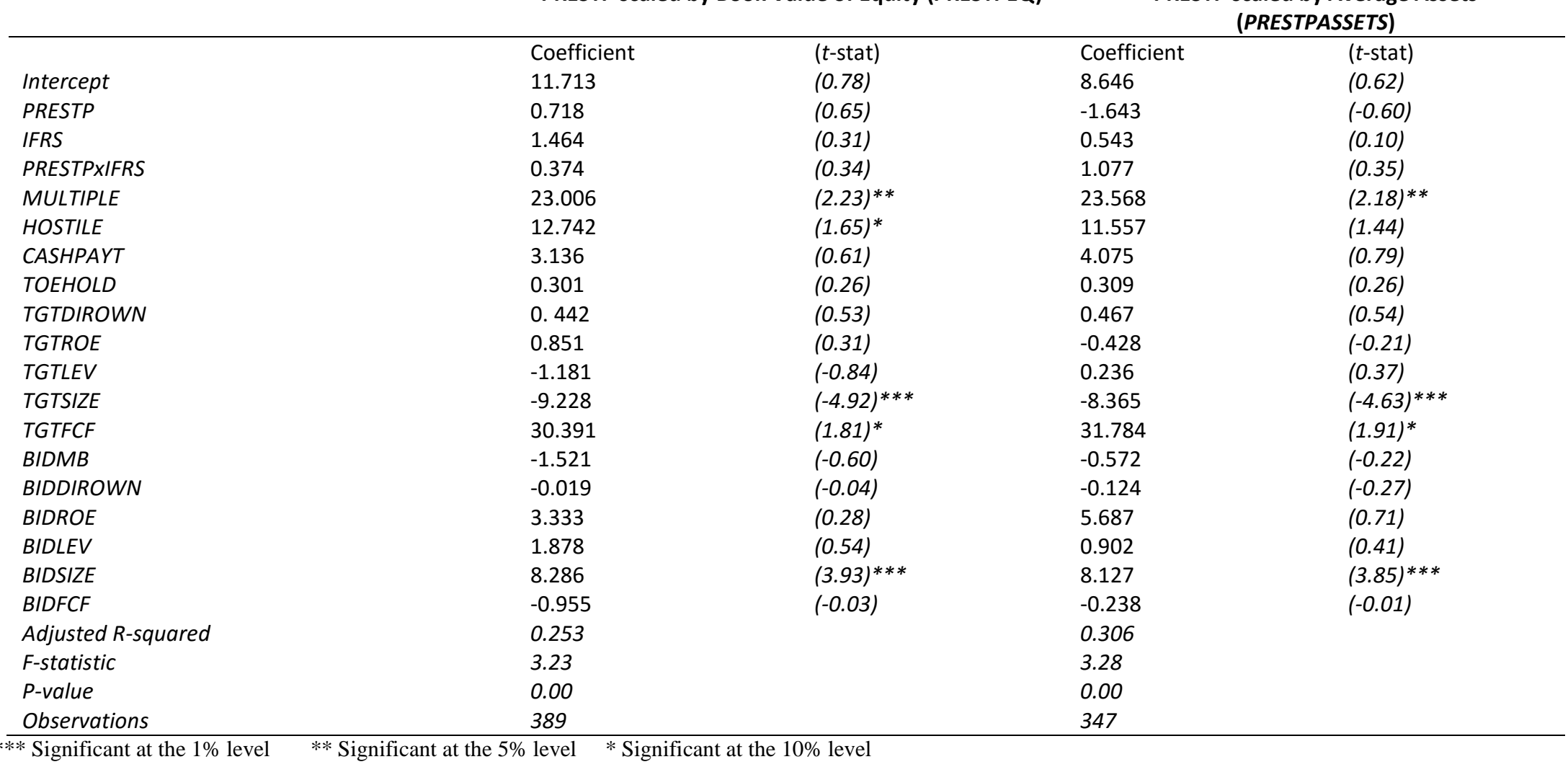

